\title{
INTERNAL MODEL FOR INSURERS: POSSIBILITIES AND ISSUES
}

\author{
Ilze ZARIN̦A ${ }^{1 *}$, Irina VORONOVA (D) ${ }^{2}$, Gaida PETTERE(D) ${ }^{3}$ \\ ${ }^{1,2}$ Department of Entrepreneurship and Management, Faculty of Engineering Economics and Management, \\ Riga Technical University, Kalncema 6, LV-1048, Riga, Latvia \\ ${ }^{3}$ Department of Engineering Mathematics, Faculty of Computer Science and Information Technology, \\ Riga Technical University, Daugavgrivas 2, LV-1048, Riga, Latvia \\ "E-mail: ilzezarina@inbox.lv
}

\begin{abstract}
Purpose - solvency II framework regulates how much capital the European Union insurance companies must hold. The amount of necessary capital can be calculated using a standard formula or an internal model. On the basis of the review of other authors' empirical research, the present paper aim at identifying factors that influence necessary capital and proposing necessary areas of improvement for the methodology of an internal capital model.
\end{abstract}

Research methodology - to conduct the paper, the authors have used the extended literature review. Analytical methods and comparative methods have been used for the Baltic non-life insurance market analysis.

Findings - the Baltic market does not use an internal model even for a major risk - premium and reserve risks. A review of the current literature findings shows that the main weakness of the standard formula is risk aggregation.

Research limitations - identified factors apply to non-life insurance companies under the Solvency II framework with a focus on reserve risk.

Practical implications - factors are identified that should be implemented in the internal model methodology. The paper will help avoid using internal models as only a modern risk management tool and improve risk profile accuracy.

Originality/Value - improvements of the internal model methodology are proposed based on a literature review. The authors have identified the main directions, issues and improvement possibilities for reaching modern risk management.

Keywords: Solvency II, capital management, economic modelling, insurance, internal model, reserve risk, possibilities, literature review.

JEL Classification: C58, G22, G32.

Conference topic: Contemporary Financial Management.

\section{Introduction}

The Solvency II framework came into effect in 2016. It regulates how much capital the European Union insurance companies and pension funds should hold to run business and be able to pay liabilities to customers, with a $99.5 \%$ confidence level in a 12-month time horizon and 1- to 200-year event occurrence frequency. The amount of necessary capital can be calculated using a standard formula or partial or full internal models. Despite the fact that the regime lasts more than three years, there is still room for improvement in risk management, considering the issues and experiences discussed in various research papers. It will avoid that internal models are not only due to modern risk management but also add risk management, capital management reality. European insurance groups continuously should resubmit and introduce internal models.

On the one hand, insurance buyers do not have to pay a higher premium due to their insurer's excessively high capital level and capital costs. On the other hand, supervisory authorities should monitor financial stability in the European Union market and create a capital model, in which the entire underlying capital amount is sufficient, sensitive to a certain risk as much as possible. The solvency capital requirement and regulators' capital requirement must be as close as possible instead of working with two models - one for internal decision-making, the second for reporting. The 2008 financial crisis provoked a regulatory onslaught against the use of internal models that is still ongoing (Embrechts, 2017). The Basel committee for the Basel III framework has started to permit the restricted use of internally-modelled approaches (Bank for International Settlements, 2017) for certain risk categories as an argument that internal models are non-transparent (Gillespie, Clark, Verheugen, \& Wells, 2008). There have not been similar discussions in the 
European Union financial regulatory institutions (The European Insurance and Occupational Pensions Authority EIOPA) yet, but national regulators can disallow an internal model. Internal capital modelling is essential due to an increase in capital costs, low investment return, and the low-interest rate environment in the European Union. It also helps implement new upcoming risks that have not been implemented yet by the EIOPA, such as cybercrimes and risk arising from digital transformation. Accenture's (2019) research results show that cyber risk could result in additional costs amounting to 4.6 trillion EUR and a profit drop in the next five years.

Over the period of 1960-2005, the Canadian insurance market found evidence that inadequate pricing and deficient loss reserves were the leading causes of insurer insolvency (Leadbetter \& Dibra, 2008; Kleffner \& Lee, 2009). The published working paper by A. M. Best (2001) summarises the primary causes of 214 insurers' insolvency in the United States of America (USA). The primary cause is under-reserving in 34 per cent of cases; in 20 per cent of cases, it is rapid growth, while in 10 per cent of cases, it is alleged fraud, and in 9 per cent of cases - investment failure (A. M. Best, 2001; Buckham, Wahl \& Rose, 2011). For the insurance sector in Canada and the USA, the historically top risk that has caused insolvency for insurers is reserve risk and growth that is too fast. The authors suggest performing a full risk assessment for these risks during their own risk solvency assessment process. The internal model should be implemented in case of significant differences when compared with the standard formula assessment. In the present study, we focus on non-life insurance reserve risk issues and possibilities, using a standard formula or an internal model. The object of the research is an internal model and its possibilities and issues, and the subject is non-life insurance companies. The goal of the paper is to identify factors that influence necessary capital and to propose an internal capital model methodology based on a literature review, a summary of other authors' empirical research. The present paper provides discussion on the components of internal capital models under the Solvency II framework and what should be done to create an efficient and accurate model. The framework is not strict in the area of internal modelling. The framework is based on the idea that insurers should know more than national regulators about their own risk profile.

The paper is organised as follows. First, a literature review is provided (Section 1). Section 2 presents an analysis of key performance and solvency indicators for the Baltic (Latvia, Lithuania, Estonia) non-life insurance market, introduces the procedure of reserve risk calculation, and discuss legislative aspects of the internal model under the Solvency II framework. Section 3 provides a description of the research methodology for literature review and for finding the factors that influence reserve risk, which will improve the internal model methodology and avoid standard formula weaknesses. Section 4 discusses areas of potential improvement of the internal model from the perspective of practitioners and researchers. The last section concludes the paper.

\section{Literature review}

Internal models are currently in use in several capital regimes, such as Basel III for the EU banking industry, Solvency II for the EU insurance industry, LITAC for life insurers in Canada, and APRA's approach for insurers in Australia. The exact definition of an internal model has not been invented under the Solvency II framework in the main European Union Commission delegated regulations - Solvency II Directive 2009/138/EC, Solvency II Regulation 2015/35. It can be explained by the fact that Solvency II is principles-based but Basel III uses a rules-based approach. The framework gives flexibility for internal model development. One of the main aspects mentioned in regulation is that the internal model shall have an important role in the system of governance of an insurance company where it is adapted to the individual risk profile and understood by the persons who base decisions on its outputs. Capital adequacy may be considered from four points of view: companies' shareholders, the rating agencies, the customers and cooperation partners, or the employees and the regulator. Different experts can have different views and understandings of what an internal model is. CEA and Groupe Consultatif (2007) use the internal model to refer to a risk management system developed by an insurer to analyse the overall risk position, to quantify risks, and to determine the economic capital required to meet those risks. The International Actuarial Association use the internal model as a mathematical model of an insurer's operations in order to analyse its overall risk position, to quantify risks, and to determine the capital needed to meet those risks. The used economic capital models can vary from simple deterministic approaches to extremely complex stochastic approaches. The exact definition of reserve risk is also not provided by the Solvency II framework, but the main idea when comparing definitions developed in research papers is the same. The only difference is that the Solvency II framework assesses reserve risk in a one-year period, which is not a good actuarial practice. The authors' proposed definition of reserve risk based on EIOPA technical specifications is a risk that the current reserves are insufficient to cover run-off over a 12-month time horizon (EIOPA, 2014). Buckham, Wahl, and Rose (2011) have defined reserve risk as a risk that additional technical provisions may have to be raised against claims of previous years. Diers and Linde (2013) have categorised reserve risk as embedding future accident years that lead to an integrated approach. It also leads to quantifying a multi-year risk that arises from the settlement of outstanding claims.

The authors of the present research have not identified studies where a literature review is used for a reserve risk standard formula. Reserves (claim best estimate) have a significant part in the economic balance sheet for non-life insurers. Different techniques have been developed to assess a reserve amount in order to reach reliable, best-practise 
results and assess potential deviation risks. Stochastic approaches such as Mack (1993) and bootstrapping (Efron, 1979) have been developed with the classical chain ladder approach as a base model. Classical approaches to assessing reserve risk for one year, as it is under the Solvency II framework, are developed by Wütrich and Bühlmann (2009), and Merz and Wütrich (2008).

\section{Description of internal models, reserve risk and Baltic non-life insurance market performance}

\subsection{Baltic non-life insurance market performance and financial stability indicators}

The present section summarises the goals of indicators based on solvency and financial stability for the Baltic non-life insurance market. This will help us understand the key performance measures in insurance, the role of risk management function in internal model implementation and capital management. In 2017, the Baltic insurance market had a $20 \%$ market share for the life insurance business and $80 \%$ for the non-life insurance business (EIOPA, 2018). The top key performance and financial stability indicators are cost ratio, expense ratios and the sum of both ratios: the combined ratio. Figure 1 demonstrates the key performance indicators of the Baltic non-life insurance market. It shows overall market results during the first quarter (Q1) of the year 2017 to the second quarter (Q2) of the year 2018 (2017Q12018Q2) with total observations of 15-17. As can be observed, the loss ratio during the period has small fluctuations, and, therefore, the main driven fluctuations for financial results are also created by cost ratios created by companies registered in Latvia.

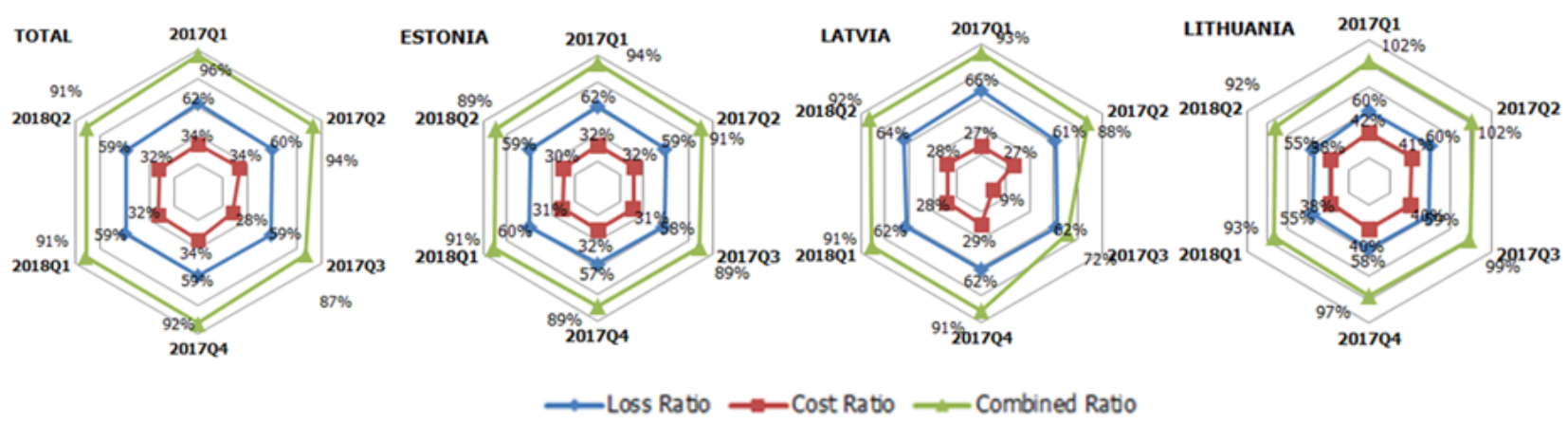

Figure 1. Key performance indicators of the Baltic overall non-life insurance market (source: created by the authors based on EIOPA Insurance Statistics, 2018)

Latvia has the highest fluctuations in cost ratio but has the lowest cost ratio in the Baltic region. Lithuania has the highest cost ratio but the lowest loss ratio. Estonia has the best overall performance and has the least combined ratio. The Estonian market is the most stable in the period under consideration. Solvency ratio is the ratio of eligible own funds (EOF) to solvency capital requirements (SCRs), and results can be seen in Figure 2.

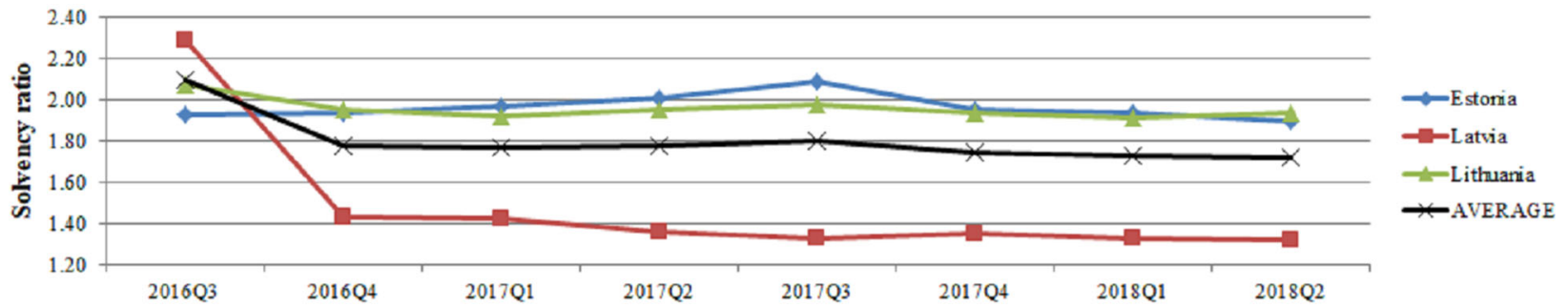

Figure 2. Solvency ratios of the Baltic non-life insurance market (ratio of eligible own funds to SCR) (source: created by the authors based on EIOPA Insurance Statistics, 2018)

For the last quarter, we cannot see significant fluctuations in solvency ratios. However, data show that SCRs have grown faster than eligible own funds (see Table 1). It can be explained by a standard formula principle - when there is higher growth in premium volume, higher capital is needed, and it is not related to future profitability. The Baltic nonlife insurance market has grown by $16 \%$ in premium volume during the period of 2017Q2 and 2018Q2, and, therefore, the SCRs have also grown faster than eligible own funds. 
Table 1. SCR, EOF changes in the Baltic overall insurance market (source: created by the authors based on EIOPA Insurance Statistics, 2018)

\begin{tabular}{|c|c|c|c|c|c|c|c|}
\hline Period: & $\begin{array}{c}\text { 2016Q4 to } \\
\text { 2016Q3 }\end{array}$ & $\begin{array}{c}\text { 2017Q1 to } \\
\text { 2016Q4 }\end{array}$ & $\begin{array}{c}2017 \mathrm{Q} 2 \text { to } \\
2017 \mathrm{Q} 1\end{array}$ & $\begin{array}{c}2017 \mathrm{Q} 3 \text { to } \\
2017 \mathrm{Q} 2\end{array}$ & $\begin{array}{c}2017 \mathrm{Q} 4 \text { to } \\
2017 \mathrm{Q} 3\end{array}$ & $\begin{array}{c}\text { 2018Q1 to } \\
2017 \text { 4 }\end{array}$ & $\begin{array}{c}\text { 2018Q2 to } \\
\text { 2018Q1 }\end{array}$ \\
\hline & \multicolumn{7}{|c|}{ SCR growth } \\
\hline Estonia & $0.5 \%$ & $3.9 \%$ & $3.6 \%$ & $-0.3 \%$ & $0.0 \%$ & $2.5 \%$ & $4.2 \%$ \\
\hline Latvia & $-9.7 \%$ & $2.7 \%$ & $5.8 \%$ & $6.8 \%$ & $1.2 \%$ & $2.7 \%$ & $0.0 \%$ \\
\hline Lithuania & $11.7 \%$ & $1.6 \%$ & $1.1 \%$ & $2.6 \%$ & $5.2 \%$ & $2.7 \%$ & $0.8 \%$ \\
\hline \multirow[t]{2}{*}{ Mean } & $1.6 \%$ & $3.0 \%$ & $3.2 \%$ & $1.9 \%$ & $1.8 \%$ & $2.6 \%$ & $2.3 \%$ \\
\hline & \multicolumn{7}{|c|}{ Total eligible own funds to meet the SCR growth } \\
\hline Estonia & $1.0 \%$ & $5.6 \%$ & $5.5 \%$ & $3.6 \%$ & $-6.4 \%$ & $1.8 \%$ & $2.4 \%$ \\
\hline Latvia & $-43.8 \%$ & $1.9 \%$ & $1.8 \%$ & $4.3 \%$ & $2.6 \%$ & $1.5 \%$ & $-1.0 \%$ \\
\hline Lithuania & $5.5 \%$ & $-0.2 \%$ & $2.7 \%$ & $4.3 \%$ & $3.0 \%$ & $1.1 \%$ & $2.5 \%$ \\
\hline Mean & $-8.0 \%$ & $3.2 \%$ & $4.1 \%$ & $3.9 \%$ & $-2.2 \%$ & $1.5 \%$ & $1.9 \%$ \\
\hline
\end{tabular}

Reserving level can be calculated as gross claim reserves divided by gross written premiums. It shows market reserving practice. Figure 3 illustrates that there is a high deviation of reserving ratio and reserving policy in the market. The authors of the present study assume that reserve risk can be significant based on calculated wide-ranging ratios year to year.

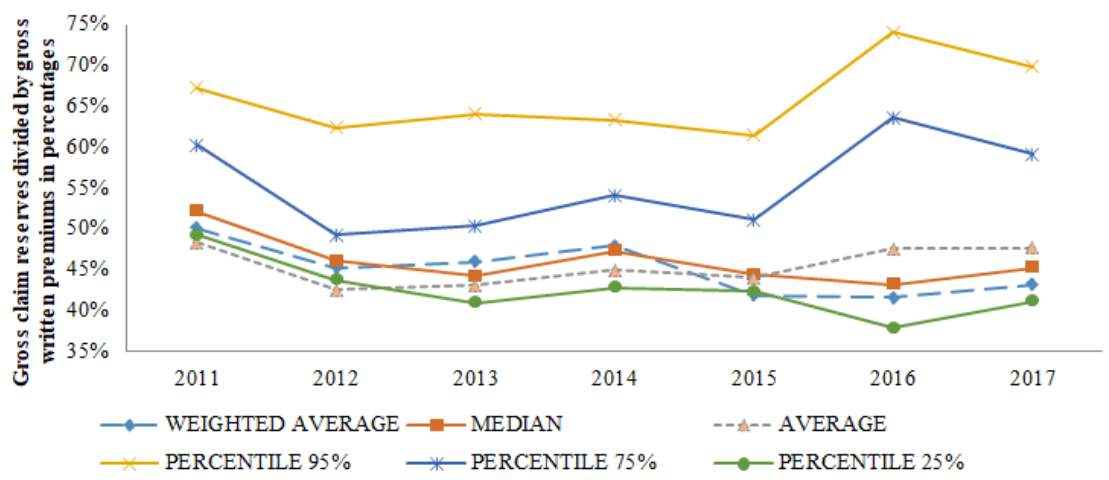

Figure 3. Reserving level development of the Baltic non-life insurance market (source: created by the authors based on BTA, ERGO, GJENSIDIGE, Lietuvos draudimas, Swedbank, IF annual financial reports 2011-2017)

Public reports on the Baltic solvency and financial condition (BTA, ERGO, GJENSIDIGE, Lietuvos draudimas, Swedbank, IF, 2017) show no use of the partial internal or full internal model. Non-life companies were mostly driven by non-life insurance risk $(56.28 \%$ ) in 2017 (see Figure 4). The top share is distributed as follows: market risk $(12.79 \%)$, operational risk $(8.59 \%)$, health underwriting risk $(8.28 \%)$ and life underwriting risk $(0.79 \%)$.

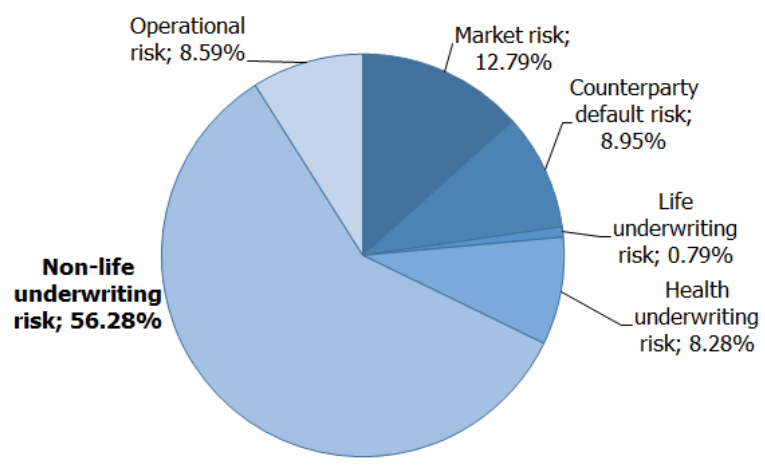

Figure 4. Risk profile of the Baltic overall non-life insurance companies representing top companies with $80 \%$ market share in 2017 (source: created by the authors based on BTA, ERGO, GJENSIDIGE, Lietuvos draudimas, Swedbank,

IF Solvency and financial stability reports 2017) 
The standard formula includes diversification between risks. Diversification effect can be calculated as the difference between the sum of all risks minus final SCRs after diversification. Diversification is usually non-hedgeable and cannot be affected, mitigated after event occurrence. The average impact of SCR diversification was $29.49 \%$ in the Baltic non-life insurance market at the end of 2017 (minimum 18\% for ERGO, maximum 35\% for BTA, IF). In the European market, the average diversification impact reveals a 16\% reduction for SCR (Krzykowski \& Lech, 2018). Diversification is vital to the capital calculation; such is the case even more so for the Baltic insurance market. This means that companies have a wide range of exposure to market risks and health, life, and non-life underwriting risks in the Baltic countries compared with the average European market. A risk profile shows the importance of risk aggregation, especially for non-life risks (premium and reserve risk, catastrophic, lapse).

\subsection{The internal model under the Solvency II framework}

The Solvency II framework has three pillars, and it is a risk-based approach model. Pillar 1 is related to the calculation of capital requirements. Risk-based capital or solvency capital requirements shall cover at least these risks (sub-risks) market risk (interest rate, equity, property, spread, currency, concentration), health underwriting risks (SLT health, catastrophic risks, non-SLT health), credit default risks, life underwriting risks (mortality, longevity, disability, lapse, expense, revision, catastrophic risks), non-life underwriting risks (premium and reserve, lapse, catastrophic risks), intangible, operational risks, an adjustment for the loss-absorbing capacity of deferred taxes, and technical provisions. Pillar 2 is related to risk management. Pillar 3 is related to disclosure management. Pillar 2 requires the own risk solvency assessment (ORSA) and the standard formula evaluation. Signs of the internal model implementation potentially creating a greater proper risk profile and signs of significant changes can already be observed during the ORSA process. If that is the case, the internal model should be created, and it can also be asked for by a financial supervisory body. The internal model is approved by a national regulator. These issues may relate not only to an economic capital model of an entire group but also to a stand-alone economic capital model of a single entity that is part of a group. Regulators have just approved a re-submitted internal model for NewRe, a Zurich-based subsidiary of Munich Re Group, and the main reason was a fully different risk profile compared with the group (NewRe, 2019).

There are three levels in the defence model under the Solvency II framework. The system of governance states that the risk management function is responsible for a proper risk profile assessment; it facilitates the risk management system and is responsible for the ORSA and SCR calculations. The main task of the actuarial function is to coordinate the calculations of technical provisions. The compliance function evaluates and facilitates the internal control system. The internal audit function provides independent and objective assurance of all processes and functions and the risk management system. Risk owners and business units are all employers who are involved in the business performance, measurement management, internal control systems and risk management systems.

An appropriate goal for financial management is to maximise the current company value (Ross, Westerfield, \& Jordan, 2016). By maximising share price, management will be maximising shareholders' shares, wealth, return on equity and shareholder value. Minimising the overall costs of the company's projects maximises the value of the company's cash flows. Figure 5 shows that the only link between capital management and enterprise risk management (ERM) structure is a link with risk appetites set by companies' supervisory boards. The higher risk appetite set in a business strategy the more capital is necessary.

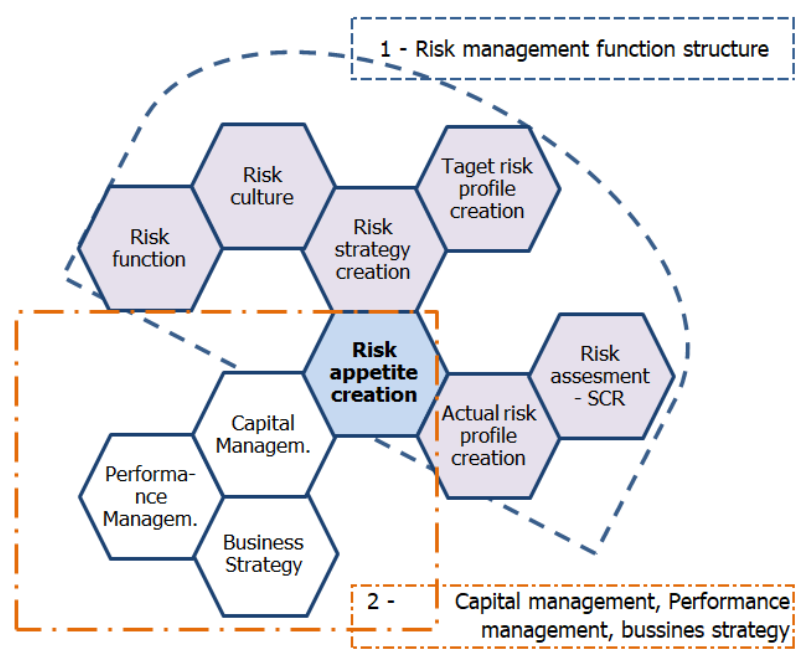

Figure 5. The link between capital management and ERM, and risk appetite (source: created by the authors based on Spencer, 2014, Proctor, 2013 and Kalịinina \& Voronova, 2013) 
In order to improve risk management and capital management, it is possible to use one of the most appropriate models: a standard formula (SF) with or without undertaking-specific parameters, a partial internal model (PIM) and a full internal model (IM). Figure 6 represents an idea: the more complex the model, the more accurate the risk profile and the higher the model's running time, development and maintenance costs. The highest costs, running time but the most precise risk profile will be achieved by using an internal model.

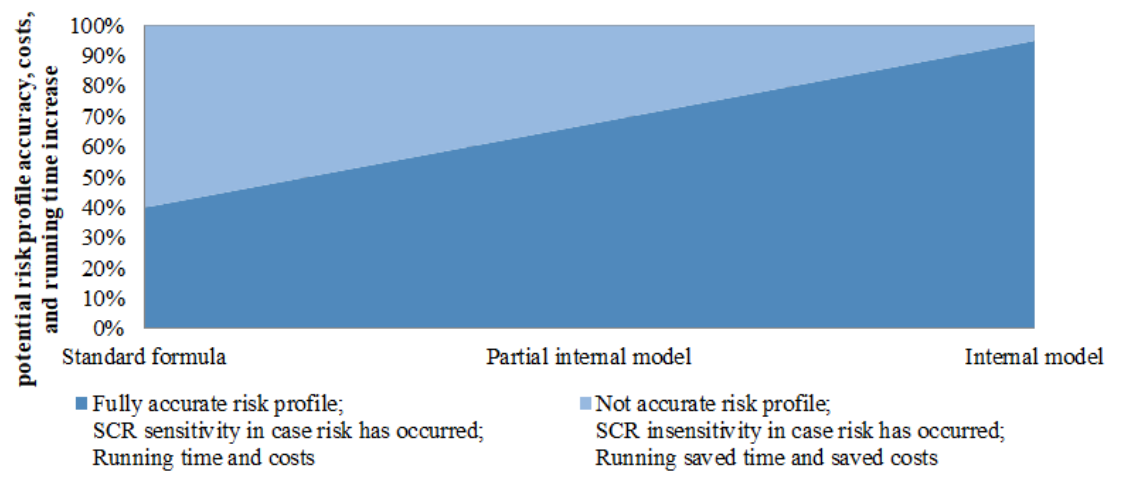

Figure 6. Example of potential risk profile accuracy, costs, and running time-based on a model used for risk-based capital calculation (authors' interpretation based on PriceWaterhouseCoopers publication, 2011)

Regulators should be updated with new risk assessment methods and continue to improve knowledge. In order to implement an internal model, regulators should keep in line with requirements according to articles from 120 to 125 of the Solvency II Directive 2009. The main issue is that the internal model needs to be individually tested by a regulator. Many standards and tasks must not only be in the documentation but also must be built into the everyday decisionmaking process and risk governance system.

Every internal model under the Solvency II framework should have these five characters and offer these possibilities. First, the model follows principles of the standard formula of the Solvency II regulation. It consists of market consistent valuation techniques and uses a value-at-risk measure with a $99.5 \%$ confidence level in the one-year horizon. The internal model must also have the regulator's previous authorisation. Second, reserves and capital must be properly set aside and allocated to each line of business and all portfolios so that the pure risk profile can be seen. Next, the precise capital allocation must retain a good reputation. In addition, there must be a balance between accuracy and simplicity, and it cannot be too costly or time-consuming. Lastly, the model must avoid all hotly discussed issues in academic journals - potential dependences between risks as a literature review in the next section demonstrates this principle.

The summary of the main internal model standards that should be implemented in the methodology and the aim of each standard are presented in Figure 7. The use test is an essential lever to achieve a positive return on income (Sia Partners, 2011). The methodology of the internal model includes model components such as model type (e.g., deterministic or stochastic), assumptions (e.g., longevity), interactions (e.g., future management actions, policyholders' behaviour), data (e.g., internal or external), IT (e.g., program used for calculations), and process (procedure, governance, internal, or external audit).

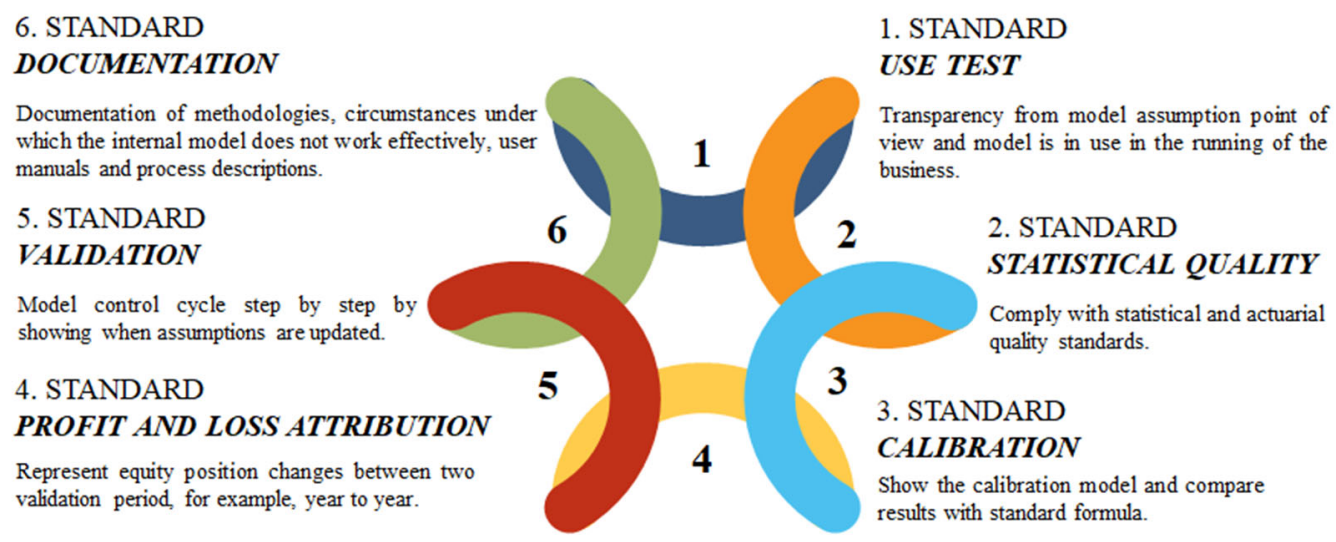

Figure 7. The main standards and their aim for internal model implementation (the authors' interpretation based on EIOPA internal model guidelines, 2014) 


\subsection{Reserve risk calculation under the Solvency II framework}

Non-life underwriting risk consists of three sub-risks: premium and reserve risk, lapse risk, and catastrophic risk. Reserve risk is calculated as the net outstanding claim reserve and a three-standard-deviation multiplication for each line of business. The standard deviation for reserve risk for each line of business is set by EIOPA. It is assumed that reserve risk follows a log-normal distribution. The linear correlation matrix provided by EIOPA is used for reserve risk aggregation. A more detailed calculation can be seen in Solvency II Regulation 2015/35. In this case, the capital requirement for reserve risk $\mathrm{SCR}_{\text {reserve }}$ is derived from the following formula:

$$
S C R_{\text {reserve }}=3 \cdot \sigma_{\text {reseve }} \cdot C B E_{\text {net }},
$$

where: $\sigma$-measures the volatility of non-life reserve risk and $C B E_{n e t}$ - the best claim estimate after reinsurance.

\section{Methodology}

The authors have been guided by the research question: What are the weaknesses of the EIOPA's standard formula for non-life reserve risk under the Solvency II framework? The answer to the question will help find capital influencing factors based on quantitative case studies. In the search process, the authors have used peer-reviewed articles of the Scopus database published between 2006 and 10 February 2019. The database has been chosen because it is the largest abstract and citation database of peer-reviewed (primary) literature. It also has a wide range of literature coverage of enterprise risk management, actuarial science and mathematics. The search starting year of 2006 has been chosen since it was for the first time when the quantitative impact study of Solvency II was published.

The keywords for the literature review are "reserve" and "capital", and "risk" and "solvency". A total of 26 papers have been selected after reviewing 54 papers. The authors have chosen four groups for weakness grouping - risk aggregation (factor 1), time horizon used for capital holding (factor 2), model type (stochastic instead of deterministic) (factor 3), and profitability (factor 4).

Risk aggregation can be interpreted as a formula that works appropriately till the risk diversification calculation is made and capital is calculated in an inappropriate way for each line of business. A time horizon can be interpreted as when capital is set in an adequate amount for a one-year horizon but must be assessed in a longer time horizon. Meanwhile, the model type can be interpreted as capital in which the risk is not even calculated in an appropriate way for each line of business. Finally, profitability can be interpreted as when risk depends on average claim costs, which can be different when comparing different regions. In the risk aggregation group, there are keywords such as correlation, dependence, diversification, aggregation, and independence. In the time horizon group, there are keywords such as a short time, one year, and not a lifetime. In the model type group, there are keywords such as distribution, deterministic, and stochastic. Finally, in the profitability group, there are keywords such as profit and loss, expected profits, and profitability. Figure 8 demonstrates a process flowchart of paper selection, rejection and classification.

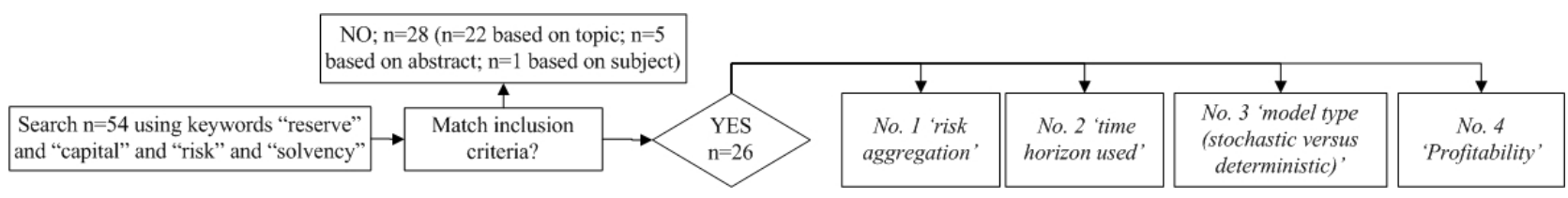

Figure 8 . The flowchart diagram of the literature review

\section{Results and discussion}

Table 2 provides an overview of factors that should be implemented in the internal model methodology and the weaknesses of the European Union standard formula for reserve risk discussed in peer-reviewed papers. The result would make it possible to avoid issues that have already been discussed in research papers. All selected papers and the classification of papers by factor group can be seen in Appendix 1 .

Table 2. The proposed factors that should be implemented in the internal model methodology for reserve risk (based on the summary of the authors' literature review and publication interpretation in Appendix 1)

\begin{tabular}{|c|c|c|c|c|}
\hline Factors: & Factor 1 & Factor 2 & Factor 3 & Factor 4 \\
\hline Coding group: & Risk aggregation & $\begin{array}{c}\text { Time horizon used for capital } \\
\text { holding }\end{array}$ & $\begin{array}{c}\text { Model type (deterministic } \\
\text { versus stochastic) }\end{array}$ & Profitability \\
\hline Total count: & 14 & 4 & 10 & 3 \\
\hline
\end{tabular}


Out of 26 papers, fourteen have mentioned the dependency problem related to risk aggregation. Non-linear risks mainly exist in the real world. Out of 26 papers, ten indicate that problems occur because insurance companies use only deterministic approaches for outstanding claim reserving. Reserve risk also depends on reserving policy, actuaries' behaviour, management actions (for example, reinsurance) and reserving sufficiency. Therefore, EIOPA's standard formula approach is too simple. Four papers state that the main problem is related to a too short time horizon for SCR calculation. Biard, Lefèvre, and Loisel (2008), Forte, Ialenti, and Pirra (2012), and Kemaloglu and Gebizlioglu (2009) have mentioned that the standard formula fits only large companies in the case of normal market conditions. Small and medium-sized companies, therefore, have the highest possible difference between current capital risk assessment using standard formulas and the appropriate capital risk assessment. The authors think that the Baltic nonlife insurance companies fall in the scope of medium-sized and small companies in the European context. Large claims, which are outliers, also have a significant impact. Out of 26 papers, three have mentioned that profitability should be taken into account. In different European regions, profit margin, risk premium and costs can vary greatly.

In order to solve the dependency problem, 14 papers propose a copula approach. The main copulas that are mentioned are the Gaussian copula (3 papers), the Clayton copula (2), the Farlie-Morgenstern copula (1 time) and the nonspecific copula (8). In order to resolve the issue of a short time period, ruin theory (1 time) and geometric Brownian motion (1) are proposed. In order to resolve deterministic and time issues, bootstrapping and Monte Carlo methods (7), regression models (3), stochastic reserving methods, including a robust chain ladder (1) and mack chain ladder (1), a generalized cap code (1), the Frohlich and Weng model (1), a neural network approach (1), a credibility approach (1) and a COT method developed by the SCOR insurance group (1) are proposed.

The authors of the present study maintain that a neural network approach and machine learning techniques will also be mentioned in the following papers, as big data algorithms are becoming more popular. The credibility approach method is also getting more popular in non-life insurance as a pricing technique. It is simple and easy to build in systems. The first step should be to test the reserve risk underlying distribution.

\section{Conclusions}

Every internal model under the Solvency II framework should have these five characteristics and provide these possibilities. First, the model follows the principles of the Solvency II regulation standard formula: It consists of market consistent valuation techniques, using value at risk measure with a $99.5 \%$ confidence level in a one-year horizon. Second, reserves and capital are properly set aside and allocated to each line of business; therefore, pure risk profiles of all portfolios can be observed. Next, precise capital allocation retains a good reputation. Then, there must be a balance between accuracy and simplicity, and it cannot be too costly or time-consuming. Finally, the model must avoid all hotly discussed issues in academic journals.

The Baltic non-life insurance market did not use internal models in the year 2017. The Baltic market does not use them even for significant risk premium and reserve risk identified by the authors.

Risk aggregation and potential dependency issues between risks are the most often mentioned factors based on other authors' empirical research. Results of the literature review show that the internal model methodology should solve the dependency problem and choose stochastic approaches. The first step should involve testing the reserve risk underlying distribution. The standard formula approach using value at risk measure and linear correlation matrix cannot solve insurance sector-specific problems.

Using the internal model is the right approach in modern risk management. Suggested topics for further research include the way of choosing the most appropriate type of copula for non-life reserve risk for a different line of business and what statistical tests can be selected in order to choose the most appropriate copula type for reserve risk.

\section{Funding}

This research received no specific grant from any funding agency in the public, commercial, or not-for-profit sectors.

\section{Disclosure statement}

The authors declared no potential conflicts of interest concerning the research, authorship, and/or publication of this article.

\section{References}

AB Lietuvos draudimas. (2017). Annual reports (2011-2017) and SFCR report (2017). Retrieved from https://www.ld.lt/privatiems-klientams/apie-kompanija/finansiniai-rezultatai

Accenture. (2019). Securing the digital economy. Retrieved from https://www.accenture.com/_acnmedia/Thought-LeadershipAssets/PDF/Accenture-Securing-the-Digital-Economy-Reinventing-the-Internet-for-Trust.p $\overline{\mathrm{d} f}$ 
Alm, J. (2015). A simulation model for calculating solvency capital requirements for non-life insurance risk. Scandinavian Actuarial Journal, 2015(2), 107-123. https://doi.org/10.1080/03461238.2013.787367

Araichi, S., \& Belkacem, L. (2014). Solvency capital for non-life insurance: Modelling dependence using copulas. Journal of Applied Economic Sciences, 9(4), 702-717.

Araichi, S., Peretti, C. D., \& Belkacem, L. (2017). Reserve modelling and the aggregation of risks using time-varying copula models. Economic Modelling, 67, 149-158. https://doi.org/10.1016/j.econmod.2016.11.016

Arbenz, P., Hummel, C., \& Mainik, G. (2012). Copula-based hierarchical risk aggregation through sample reordering. Insurance: Mathematics and Economics, 51(1), 122-133. https://doi.org/10.1016/j.insmatheco.2012.03.009

BALTA. (2017). Annual reports (2011-2017) and SFCR report (2017). Retrieved from http://www.balta.lv/lv/par-mums/darbibasrezultati

Bank for International Settlements. (2017). Basel III: Finalising post-crisis reforms. Retrieved from https://www.bis.org/bcbs/publ/d424.pdf

Bargès, M., Cossette, H., \& Marceau, É. (2009). TVaR-based capital allocation with copulas. Insurance: Mathematics and Economics, 45(3), 348-361. https://doi.org/10.1016/j.insmatheco.2009.08.002

Bermúdez, L., Ferri, A., \& Guillén, M. (2013). A correlation sensitivity analysis of non-life underwriting risk in solvency capital requirement estimation. Astin Bulletin, 43(1), 21-37. https://doi.org/10.1017/asb.2012.1

Biard, R., Lefèvre, C., \& Loisel, S. (2017). Impact of correlation crises in risk theory: Asymptotics of finite-time ruin probabilities for heavy-tailed claim amounts when some independence and stationarity assumptions are relaxed. Insurance: Mathematics and Economics, 43(3), 412-421. https://doi.org/10.1016/j.insmatheco.2008.08.004

Bølviken, E., \& Guillen, M. (2017). Risk aggregation in Solvency II through recursive log-normals. Insurance: Mathematics and Economics, 73, 20-26. https://doi.org/10.1016/j.insmatheco.2016.12.006

BTA. (2017). Annual reports (2011-2017) and SFCR report (2017). Retrieved from https://www.bta.lv/lv/about/finansu-raditaji\#2016-gads

Buckham, D., Wahl, J., \& Rose, S. (2011). Executive's Guide to Solvency II. Wiley. https://doi.org/10.1002/9781119200710

Butaci, C., Dzitac, S., Dzitac, I., \& Bologa, G. (2017). Prudent decisions to estimate the risk of loss in insurance. Technological and Economic Development of Economy, 23(2), 428-440. https://doi.org/10.3846/20294913.2017.1285365

CEA - Groupe Consultatif. (2007). Solvency II Glossary. Brussels, Belgium: Comité Européen des Assurances and Groupe Consultatif Actuariel Europeen.

Clemente, G. P., \& Savelli, N. (2017). Actuarial improvements of standard formula for non-life underwriting risk. In P. Marano \& M. Siri (Eds.), Insurance regulation in the European Union: Solvency II and Beyond (pp. 223-243). Cham, Switzerland: Springer International Publishing. https://doi.org/10.1007/978-3-319-61216-4_10

Dacorogna, M., Ferriero, A., \& Krief, D. (2018). One-year change methodologies for fixed-sum insurance contracts. Risks, 6(3),75. https://doi.org/10.3390/risks6030075

Diers, D., \& Linde, M. (2013). The multi-year non-life insurance risk in the additive loss reserving model. Insurance: Mathematics and Economics, 52(3), 590-598. https://doi.org/10.1016/j.insmatheco.2013.03.004

Diers, D., Eling, M., \& Linde, M. (2013). Modelling parameter risk in premium risk in multi-year internal models. Journal of Risk Finance, 14(3), 234-250. https://doi.org/10.1108/JRF-11-2012-0084

Efron, B. (1979). Bootstrap methods: another look at the jackknife, Annals of Statistics, 7(1), 1-26. https://doi.org/10.1214/aos/1176344552

EIOPA. (2014). Consultation Paper on the proposal for Implementing Technical Standards on internal models approval processes. Frankfurt, Germany: EIOPA. Retrieved from https://eiopa.europa.eu/Publications/Consultations/EIOPA-CP-14005_ITS_Approval_Processes_IM.pdf

EIOPA. (2014). Technical specification for the preparatory phase. Retrieved from https://eiopa.europa.eu/Publications/ Standards/ A_-_Technical_Specification_for_the_Preparatory_Phase_Part_I_pdf

EIOPA. (2018). Insurance Statistics quarterly data Q3 2016 - Q3 2018 by country. Retrieved from EIOPA website: https://eiopa.europa.eu/pages/financial-stability-and-crisis-prevention/insurance-statistics.aspx

Embrechts, P. (2017). A Darwinian view on internal models. Journal of Risk, 20(1), 1-21. https:// doi.org/10. 21314/JOR.2017.394

England, P. D., Verrall, R. J., \& Wüthrich, M. V. (2019). On the lifetime and one-year views of reserve risk, with application to IFRS 17 and Solvency II risk margins. Insurance: Mathematics and Economics, 85, $74-88$. https://doi.org/10.1016/j.insmatheco.2018.12.002

ERGO. (2017). Annual reports (2011-2017) and SFCR report (2017). Retrieved from https://www.ergo.ee/fsfiles/0000/0000/0002/files/SFCR\%20report\%20Non-Life\%20EST\%202017\%20final\%20web.pdf

European Parliament, \& Council of the European Union. (2009). Directive 2009/138/EC of the European Parliament and of the Council of 25 November 2009 on the taking-up and pursuit of the business of Insurance and Reinsurance (Solvency II). Retrieved from https://eur-lex.europa.eu/legal-content/EN/TXT/PDF/?uri=CELEX:32009L0138\&from=EN

European Parliament, \& Council of the European Union. (2014). Regulation 2015/35/EC of the European Parliament and of the Council of 10 October 2014 supplementing Directive 2009/138/EC of the European Parliament and of the Council on the taking-up and pursuit of the business of Insurance and Reinsurance (Solvency II).

Ferriero, A. (2016). Solvency capital estimation, reserving cycle and ultimate risk. Insurance: Mathematics and Economics, 68, 162-168. https://doi.org/10.1016/j.insmatheco.2016.03.004 
Fersini, P., \& Melisi, G. (2016). Stochastic model to evaluate the fair value of motor third-party liability under the direct reimbursement scheme and quantification of the capital requirement in a solvency II perspective. Insurance: Mathematics and Economics, 68, 27-44. https://doi.org/10.1016/j.insmatheco.2016.02.002

Forte, S., Ialenti, M., \& Pirra, M. (2012). Claims reserving uncertainty in the development of internal risk models. In C. Perna, \& M. Sibillo (Eds), Mathematical and statistical methods for actuarial sciences and finance (pp. 203-210). Springer, Milano. https://doi.org/10.1007/978-88-470-2342-0_24

Fröhlich, A., \& Weng, A. (2018). Parameter uncertainty and reserve risk under Solvency II. Insurance: Mathematics and Economics, 81, 130-141. https://doi.org/10.1016/j.insmatheco.2017.10.004

Gillespie, O., Clark, D., Verheugen, H., \& Wells, G. (2008). Benefits and challenges of using an internal model for Solvency II. (Milliman White Paper 2008). London, United Kingdom: Milliman, Inc.

GJENSIDIGE. (2017). Annual reports (2011-2017) and SFCR report (2017). Retrieved from https://www.gjensidige.lt/apiemus/finansiniai-rezultatai

Hejazi, S. A., \& Jackson, K. R. (2017). Efficient valuation of SCR via a neural network approach. Journal of Computational and Applied Mathematics, 313, 427-439. https://doi.org/10.1016/j.cam.2016.10.005

IF. (2017). Annual reports (2011-2017) and SFCR report (2017). Retrieved from https://www.if.ee/ifist/meist/finantsandmed

Kaḷinina, D., \& Voronova, I. (2013). Risk Management Improvement under the Solvency II Framework. Economics and Business, 24, 29-36. https://doi.org/10.7250/eb.2013.004

Kemaloglu, S. A., \& Gebizlioglu, O. L. (2009). Risk analysis under progressive type II censoring with binomial claim numbers. Journal of Computational and Applied Mathematics, 233(1), 61-72. https://doi.org/10.1016/j.cam.2008.10.045

Kleffner, A., \& Lee, R. (2009). An examination of property \& casualty insurer solvency in Canada. Journal of Insurance Issues, 32(1), 52-77. Retrieved from http://www.jstor.org/stable/41946291

Krzykowski, M., \& Lech, J. (2018). Analysis of life insurers' Solvency and Financial Condition Reports (Milliman Research report 2018). (Milliman White Paper 2008). Warsaw, Poland: Milliman, Inc.

Leadbetter, D., \& Dibra, S. (2008). Why insurers fail: The dynamics of property and casualty insurance insolvency in Canada. Geneva Paper Risk Insurance Issues Practise, 33(3), 464-488. https://doi.org/10.1057/gpp.2008.14

Mack, T. (1993). Distribution-free calculation of the standard error of chain ladder reserve estimates. Astin Bulletin, 23(2), 213-225. https://doi.org/10.2143/AST.23.2.2005092

Massey, R., David, H., Widdows, J., Law, D., Bhattacharya, K., Hawes, W., \& Shaw, R. (2001). Insurance Company Failure (A.M.Best Working Party Report 2001). Oldwick, United States: A. M. Best.

Moro, E. D., \& Krvavych, Y. (2017). Probability of sufficiency of solvency ii reserve risk margins: practical approximations. Astin Bulletin, 47(3), 737-785. https://doi.org/10.1017/asb.2017.12

Munroe, D., Odell, D., Sandler, S., \& Zehnwirth, B. (2015). A solution for Solvency II quantitative requirements modelling with long-tail liabilities. North American Actuarial Journal, 19(2), 79-93. https://doi.org/10.1080/10920277.2014.997934

NewRe. (2019). Modelling team of the year: NewRe. Retrieved from https://www.insuranceerm. $\mathrm{com} /$ content/galleries/insuranceerm-annual-awards-2018-2019-UK-and-europe/modelling-team-of-the-year-newre.html

Ohlsson, E., \& Lauzeningks, J. (2009). The one-year non-life insurance risk. Insurance: Mathematics and Economics, 45(2), 203208. https://doi.org/10.1016/j.insmatheco.2009.06.001

PricewaterhouseCoopers. (2011). Is a full internal model a step too far?

Proctor, K. (2013). Why risk management and strategic planning must synch. Retrieved from http://m.bankingexchange.com/ newsfeed/item/1925-why-risk-management-strategic-planning-must-synch

Ross, S. A., Westerfield, R., \& Jordan, B. D. (2016). Fundamentals of corporate finance (11th ed.). California: McGraw-Hill Education.

Savelli, N., \& Clemente, G. P. (2011). Hierarchical structures in the aggregation of premium risk for insurance underwriting. Scandinavian Actuarial Journal, (3), 193-213. https://doi.org/10.1080/03461231003703672

Sia Partners. (2011). Solvency II reform makes sense through the use test. Retrieved from http://en.finance.siapartners.com/solvency-ii-reform-makes-sense-through-use-test

Slim, N., \& Mansouri, F. (2015). Reserve risk analysis and dependence modelling in non-life insurance: The Solvency II project. Journal of Applied Economic Sciences, 10(7), 1125-1144.

Spencer, J. (2014). Own Risk \& Solvency Assessment (ORSA): The heart of Risk \& Capital Management [PowerPoint slides]. Retrieved from https://www.slideserve.com/miles/own-risk-solvency-assessment-orsa-the-heart-of-risk-capital-management

Van Wouwe, M., Verdonck, T., \& Van Rompay, K. (2009). Application of classical and robust chain-ladder methods: Results for the Belgian non-life business. Global Business and Economics Review, 11(2), 99-115. https://doi.org/10.1504/GBER.2009.028979

Wütrich, M. V., \& Bühlmann, H. (2009). The One-Year Runoff Uncertainty for Discounted Claims Reserves. Giornale dell Istituto Italiano degli Attuari, LXXI, 1-37.

Wütrich, M. V., Merz, M., \& Lysenko, N. (2009). Uncertainty in the claims development results in the chain ladder method. Scandinavian Actuarial Journal, 109(1), 63-84. https://doi.org/10.1080/03461230801979732 


\section{Appendix 1}

\section{Literature review results}

\begin{tabular}{|c|c|c|c|c|c|}
\hline & Factors: & Factor 1 & Factor 2 & Factor 3 & Factor 4 \\
\hline No. & Papers' authors: & $\begin{array}{c}\text { Risk } \\
\text { aggregation }\end{array}$ & $\begin{array}{c}\text { Time } \\
\text { horizon used }\end{array}$ & $\begin{array}{l}\text { Model } \\
\text { type }\end{array}$ & Profitability \\
\hline 1 & Alm, J. (2015) & + & & & \\
\hline 2 & Araichi, S., \& Belkacem, L. (2014) & + & & & \\
\hline 3 & Araichi, S., Peretti, C. D., \& Belkacem, L. (2017) & + & & & \\
\hline 4 & Arbenz, P., Hummel, C., \& Mainik, G. (2012) & + & & & \\
\hline 5 & Bargès, M., Cossette, H., \& Marceau, É. (2009) & + & & & \\
\hline 6 & Bermúdez, L., Ferri, A., \& Guillén, M. (2013) & + & & & + \\
\hline 7 & Biard, R., Lefèvre, C.,\& Loisel, S. (2008) & + & & & \\
\hline 8 & Bølviken, E.,\& Guillen, M. (2017) & + & & & \\
\hline 9 & Butaci, C., Dzitac, S., Dzitac, I., \& Bologa, G. (2017) & + & & & \\
\hline 10 & Clemente, G. P., \& Savelli, N. (2017) & + & & & + \\
\hline 11 & Dacorogna, M., Ferriero, A., \& Krief, D. (2018) & & & + & \\
\hline 12 & Diers, D., \& Linde, M. (2013) & & + & & \\
\hline 13 & Diers, D., Eling, M., \& Linde, M. (2013) & & & + & \\
\hline 14 & England, P. D., Verrall, R. J., \& Wüthrich, M. V. (2019) & & + & & \\
\hline 15 & Ferriero, A. (2016) & + & & & \\
\hline 16 & Fersini, P., \& Melisi, G. (2016) & & & + & \\
\hline 17 & Forte, S., Ialenti, M., \& Pirra, M. (2012) & & + & + & \\
\hline 18 & Fröhlich, A., \& Weng, A. (2018) & & & + & \\
\hline 19 & Hejazi, S.A.,\& Jackson, K.R. (2017) & & & + & \\
\hline 20 & Kemaloglu, S.A.,\& Gebizlioglu, O.L. (2009) & & & + & \\
\hline 21 & Moro, E. D., \& Krvavych, Y. (2017) & + & & + & \\
\hline 22 & Munroe, D., Odell, D., Sandler, S., \& Zehnwirth, B. (2015) & & & + & \\
\hline 23 & Ohlsson, E., \& Lauzeningks, J. (2009) & & + & & \\
\hline 24 & Savelli, N., \& Clemente, G. P. (2011) & + & & & + \\
\hline 25 & Slim, N., \& Mansouri, F. (2015) & + & & & \\
\hline \multirow[t]{2}{*}{26} & Van Wouwe, M., Verdonck, T., \& Van Rompay, K. (2009) & & & + & \\
\hline & Total count & 14 & 4 & 10 & 3 \\
\hline
\end{tabular}

